Article

\title{
Precise Regulation of the Basal PKC $\gamma$ Activity by DGK $\gamma$ Is Crucial for Motor Coordination
}

\author{
Ryosuke Tsumagari ${ }^{1}$, Kenta Maruo ${ }^{1}$, Sho Kakizawa ${ }^{2}$, Shuji Ueda ${ }^{1}$, Minoru Yamanoue ${ }^{1}$, \\ Hiromitsu Saito ${ }^{3}$, Noboru Suzuki ${ }^{3}$ and Yasuhito Shirai ${ }^{1, *}$ (1) \\ 1 Department of Applied Chemistry in Bioscience, Graduate School of Agricultural Sciences, Kobe University, \\ Kobe 657-8501, Japan; gyama_rin5334@yahoo.co.jp (R.T.); 205a421a@stu.kobe-u.ac.jp (K.M.); \\ uedas@people.kobe-u.ac.jp (S.U.); yamanoue@kobe-u.ac.jp (M.Y.) \\ 2 Department of Biological Chemistry, Graduate School of Pharmaceutical Sciences, Kyoto University, \\ Kyoto 606-8501, Japan; kakizawa.sho.4u@kyoto-u.ac.jp \\ 3 Department of Animal Functional Genomics of Advanced Science Research Promotion Center, \\ Mie University Organization for the Promotion of Regional Innovation, Tsu 514-8507, Japan; \\ hisaito@doc.medic.mie-u.ac.jp (H.S.); nsuzuki@doc.medic.mie-u.ac.jp (N.S.) \\ * Correspondence: shirai@kobe-u.ac.jp; Tel.: +81-078-803-5887
}

Received: 18 September 2020; Accepted: 21 October 2020; Published: 23 October 2020

\begin{abstract}
Diacylglycerol kinase $\gamma$ (DGK $\gamma$ ) is a lipid kinase to convert diacylglycerol (DG) to phosphatidic acid (PA) and indirectly regulates protein kinase $\mathrm{C} \gamma(\mathrm{PKC} \gamma)$ activity. We previously reported that the basal PKC $\gamma$ upregulation impairs cerebellar long-term depression (LTD) in the conventional DGK $\gamma$ knockout (KO) mice. However, the precise mechanism in impaired cerebellar LTD by upregulated PKC $\gamma$ has not been clearly understood. Therefore, we first produced Purkinje cell-specific DGK $\gamma$ KO (tm1d) mice to investigate the specific function of DGK $\gamma$ in Purkinje cells and confirmed that tm1d mice showed cerebellar motor dysfunction in the rotarod and beam tests, and the basal PKC $\gamma$ upregulation but not PKC $\alpha$ in the cerebellum of tm1d mice. Then, the LTD-induced chemical stimulation, K-glu $(50 \mathrm{mM} \mathrm{KCl}$ $+100 \mu \mathrm{M}$, did not induce phosphorylation of PKC $\alpha$ and dissociation of GluR2 and glutamate receptor interacting protein (GRIP) in the acute cerebellar slices of tm1d mice. Furthermore, treatment with the PKC $\gamma$ inhibitor, scutellarin, rescued cerebellar LTD, with the phosphorylation of PKC $\alpha$ and the dissociation of GluR2 and GRIP. In addition, nonselective transient receptor potential cation channel type 3 (TRPC3) was negatively regulated by upregulated PKC $\gamma$. These results demonstrated that DGK $\gamma$ contributes to cerebellar LTD by regulation of the basal PKC $\gamma$ activity.
\end{abstract}

Keywords: DGK $\gamma$; PKC $\gamma$; LTD; motor coordination; TRPC3

\section{Introduction}

Long-term depression (LTD) is one of the synaptic plasticity at synapses between parallel fibers (PFs) and Purkinje cells and is important for cerebellar motor coordination. LTD is induced by co-stimulation of PFs and climbing fiber (CF), which trigger the activation of metabotropic glutamate receptor 1 (mGluR1) signaling and the depolarization, leading to protein kinase $C(P K C)$ activation [1-3]. PKC promotes the phosphorylation of Ser880 in the GluR2 subunit of $\alpha$-amino- 3-hydroxy-5-methylisoxazole-4-propionic acid (AMPA) receptor, causing clathrin-mediated endocytosis [4,5]. Among PKC subtypes, PKC $\alpha$ is required for the phosphorylation of Ser880 in GluR2, leading to LTD induction [6], and the spatial regulation of PKC $\alpha$ activity contributes to cerebellar LTD [7]. Although PKC $\gamma$ is a major PKC isoform in Purkinje cells and PKC $\gamma$ deficiency causes motor dyscoordination, cerebellar LTD was not impaired in PKC $\gamma$ knockout $(\mathrm{KO})$ mice [8,9]. On the other hand, constitutive active PKC $\gamma$ mutant causes both the impairments of motor coordination and LTD [10]. These reports indicate that the precise regulation of PKC activity is responsible for cerebellar LTD and motor coordination. 
Diacylglycerol kinase (DGK) is a lipid kinase terminating diacylglycerol (DG) signaling by converting DG to phosphatidic acid (PA) [11]. DG is an important lipid messenger that activates several enzymes including protein kinase $\mathrm{C}$ (PKC) [12]. PA also regulates various enzymes including mammalian target of rapamycin (mTOR) [13]. Therefore, DGK is thought to have the important physiological roles related to DG signaling. Among DGK subtypes, the $\gamma$ isoform of DGK (DGK $\gamma$ ) is abundantly expressed in cerebellar Purkinje cells [14], and we recently reported that the conventional DGK $\gamma$ KO mice showed impaired cerebellar LTD and motor dysfunction [15]. We also found abnormal upregulation of the basal PKC $\gamma$ activity in DGK $\gamma$ KO mice and that the PKC $\gamma$ inhibitor normalized the impairment of LTD in DGK $\gamma$ KO mice [15]. These results suggested that the functional correlation between DGK $\gamma$ and PKC $\gamma$ is responsible for LTD induction. However, it remains unknown how the upregulated PKC $\gamma$ impairs cerebellar LTD in DGK $\gamma$ KO mice.

In addition, although DGK $\gamma$ also is abundantly expressed in other region of the brain including hippocampal pyramidal cells [14], the DGK $\gamma$ KO mice used in the previous study lost the enzyme in the whole body. Therefore, in the present study, we newly produced Purkinje cell-specific DGK $\gamma$ KO (tm1d) mice and investigated the specific function of DGK $\gamma$ in Purkinje cells and the detailed mechanism of PKC $\gamma$ in impaired LTD. We confirmed that Purkinje cell-specific DGK $\gamma$ KO (tm1d) mice showed impairment of motor coordination similarly to the conventional DGK $\gamma \mathrm{KO}$ mice and found that the upregulated basal PKC $\gamma$ activity negatively regulated PKC $\alpha$ inactivation during cerebellar LTD by the phosphorylation of a nonselective transient receptor potential cation channel type 3 (TRPC3). Our research demonstrates the important novel function of DGK $\gamma$ and $\mathrm{PKC} \gamma$ in the cerebellar LTD and motor coordination.

\section{Results}

\subsection{Motor Dyscoordination in Purkinje Cell-Specific DGK $\gamma$ KO (tm1d) Mice}

To investigate the specific function of DGK $\gamma$ in Purkinje cells, we produced Purkinje cell-specific DGK $\gamma$ KO (tm1d) mice by mating DGK $\gamma$ floxed (tm1c) mice and L7/Pcp2-specific Cre recombinase transgenic mice using the Cre-loxP recombination system (Figure 1a,b). The genotypes of DGK $\gamma$ gene and Cre gene were confirmed by PCR (Figure 1c,d). We examined the DGK $\gamma$ expression levels in the brain of tm1d mice using western blotting and found that the DGK $\gamma$ expression was significantly decreased at 16 weeks old (about 50\%) in the cerebellum but not in the cerebrum (Figure 1e). The reason why the expression did not disappear completely was due to DGK $\gamma$ expression in the granule cells [15]. Thus, we tested the motor coordination of tm1d mice by the rotarod and beam tests. In the rotarod test, tm1c and tm1d mice showed steady improvements over trials, but the latency for tm1d mice to fall from the rod was significantly shorter than that of tm1c mice (Figure 2a: tm1c 1, $133 \pm 20.0$; tm1d 1, $79 \pm 8.8 ;$ tm1c 2, $155 \pm 17.0 ;$ tm1d 2, $105 \pm 10.9 ; \operatorname{tm} 1 \mathrm{c} 3,200 \pm 21.5 ; \operatorname{tm} 1 \mathrm{~d} 3,122 \pm 17.6$; tm1c 4, $191 \pm 14.2 ;$ tm1d 4, $114 \pm 15.9 ;$ tm1c 5, $242 \pm 22.5 ;$ tm1d 5, $127 \pm 19.4 ; \mathrm{tm} 1 \mathrm{c} 6,264 \pm 23.8$; and $\operatorname{tm} 1 \mathrm{~d} 6,168 \pm 35.4)$. In the beam test, the tm1d mice showed more frequent slips than $\mathrm{tm} 1 \mathrm{c}$ mice (Figure $2 \mathrm{~b}$ : tm1c, $0.45 \pm 0.12 ; \mathrm{tm} 1 \mathrm{~d}, 2.53 \pm 0.79$ ). These results clearly indicated that the $\mathrm{tm} 1 \mathrm{~d}$ mice showed cerebellar motor dyscoordination. 

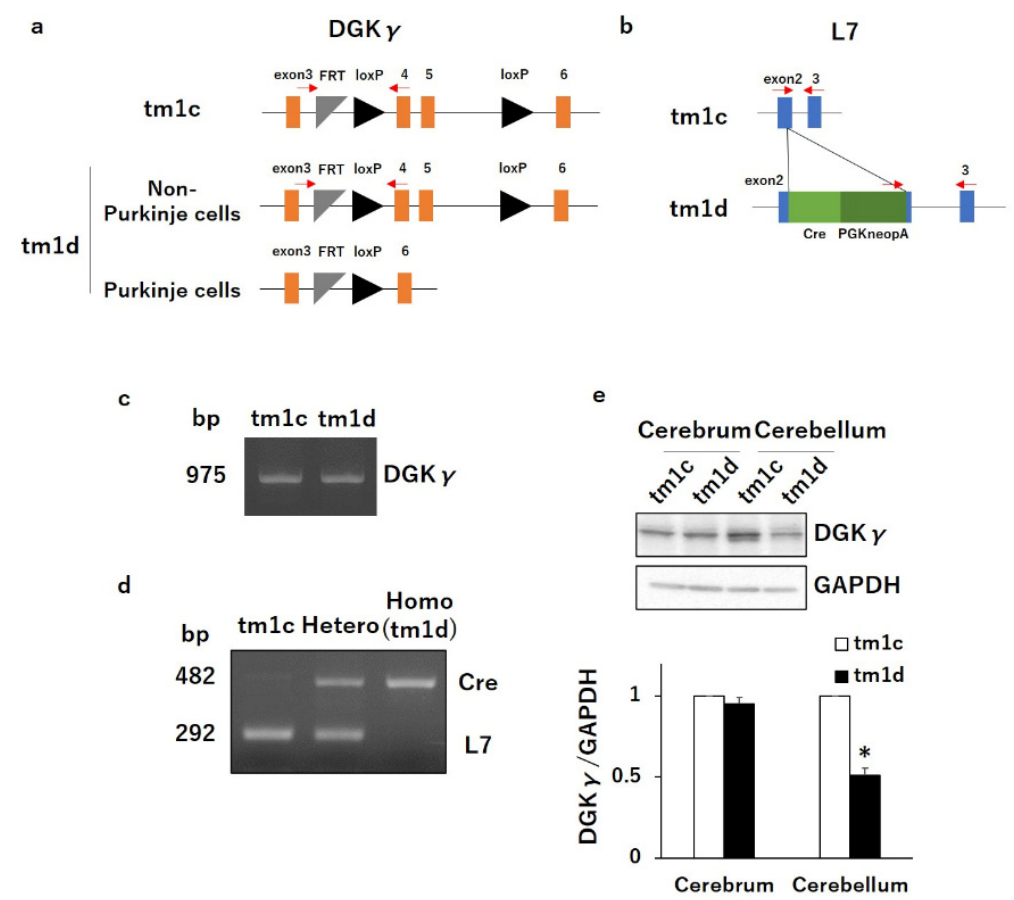

Figure 1. Generation of Purkinje cell-specific Diacylglycerol kinase $\gamma(\mathrm{DGK} \gamma)$ knockout (KO) (tm1d) mice and PCR genotyping: tm1c and tm1d alleles encodes DGK $\gamma(\mathbf{a})$ and Cre recombinase knock-in L7 (b). Cre, Cre recombinase; FRT, flippase recognition target; loxP, Cre recombinase recognition sequence; PGKneopA, PGK-neomycin cassette. PCR genotyping of DGK $\gamma$ gene (c) and Cre recombinase (d) was determined using tail-derived genome: bands at 975, 482, and 292 bp were expected for the DGK $\gamma$, Cre, and L7 alleles, respectively. Red arrows show the primer sites for PCR genotyping. (e) Cerebral and cerebellar lysates from tm1c and tm1d mice were subjected to Western blotting and probed with an anti-DGK $\gamma$ antibody. Quantification of the expression levels of DGK $\gamma$ was performed by ImageJ. The expression level of DGK $\gamma$ was normalized to the expression level of the loading control (Glyceraldehyde 3-phosphate dehydrogenase: GAPDH). $(\mathrm{n}=3) ;{ }^{*} p<0.05$, followed by Student's t-test. Data are expressed as mean \pm SEM.
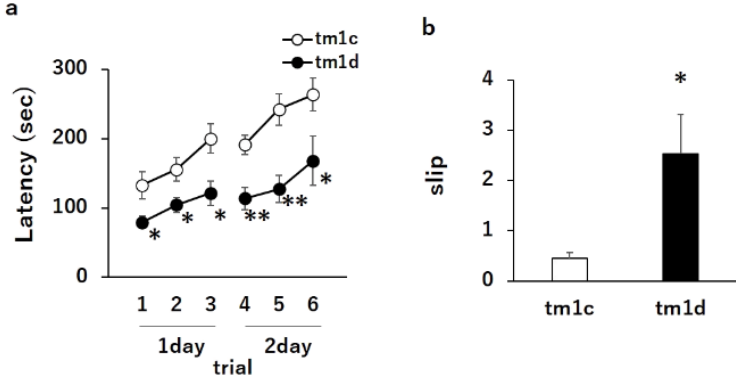

Figure 2. Motor dyscoordination in tm1d mice: (a) motor coordination of tm1c and tm1d mice at 16 weeks old was assessed by the accelerating rotarod test. The test was performed three times daily for 2 day (tm1c: $\mathrm{n}=6$; m1d: $\mathrm{n}=5$ ); ${ }^{*} p<0.05,{ }^{* *} p<0.01$, followed by Student's t-test. (b) Motor coordination of tm1c and tm1d mice was assessed by the number of hind paw slips in the beam test. The test was performed five times daily for 2 day ( $\operatorname{tm} 1 \mathrm{c}: \mathrm{n}=6$; $\mathrm{tm} 1 \mathrm{~d}: \mathrm{n}=5$ ); ${ }^{*} p<0.05$, followed by Student's t-test. Data are expressed as mean \pm SEM.

\subsection{PKC $\alpha$ Inactivation during LTD by Upregulated PKC $\gamma$ Mediated Negative Regulation of TRPC3}

We previously reported that PKC $\gamma$ activity is regulated by DGK $\gamma$ and that the upregulation of basal PKC $\gamma$ causes motor dyscoordination $[15,16]$. To investigate the molecular mechanism of motor dyscoordination in tm1d mice, we examined the autophosphorylation level of PKC $\gamma$ as a hallmark of PKC activity in the cerebellum of tm1d mice. Western blotting revealed that the phosphorylation 
level of PKC $\gamma$ was higher in the cerebellum of $\mathrm{tm} 1 \mathrm{~d}$ mice than in that of $\mathrm{tm} 1 \mathrm{c}$ mice (Figure $3 \mathrm{a}: \mathrm{tm} 1 \mathrm{c}$, 1.00; tm1d, $1.30 \pm 0.10$ ). Also, we checked the basal phosphorylation level of PKC $\alpha$ based on previous studies demonstrating that PKC $\alpha$ plays a critical role in motor coordination [6,17]. However, the basal phosphorylation level of PKC $\alpha$ in tm1d mice was equivalent to that in $\mathrm{tm} 1 \mathrm{c}$ mice (Figure 3a: $\mathrm{tm} 1 \mathrm{c}, 1.00$; $\mathrm{tm} 1 \mathrm{~d}, 1.00 \pm 0.070$ ). These results suggested that the upregulation of basal PKC $\gamma$ activity in $\mathrm{tm} 1 \mathrm{~d}$ mice causes the impairment of motor coordination, similarly seen in the conventional DGK $\gamma$ KO mice [15].

LTD stimulation induced the activation of PKC $\alpha$, which is important for the expression of cerebellar LTD [6]. Therefore, we investigated whether PKC $\alpha$ was activated during LTD in tm1d mice, although the basal PKC $\alpha$ activity was not changed. We prepared cerebellar slices $(300 \mu \mathrm{m})$ from tm1c and tm1d mice and chemically induced cerebellar LTD with K-glu (50 mM KCl $+100 \mu \mathrm{M}$ Glu) treatment for $5 \mathrm{~min}$. K-glu did not affect the phosphorylation level of PKC $\gamma$ in tm1c and tm1d mice, indicating that PKC $\gamma$ activity is not changed during LTD in both mice (Figure $3 \mathrm{~b}: \mathrm{tm} 1 \mathrm{c}$ con, 1.00; tm1c K-glu, $1.10 \pm 0.15$; tm1d con, $1.73 \pm 0.11$; tm1d K-glu, $1.54 \pm 0.092$ ). On the other hand, $\mathrm{K}$-glu induced the PKC $\alpha$ phosphorylation in the cerebellar slices from tm1c mice but not in that from tm1d mice (Figure 3b: tm1c con, 1.00; tm1c K-glu, $1.25 \pm 0.037$; tm1d con, $1.07 \pm 0.038$; tm1d K-glu, $1.10 \pm 0.068$ ). Furthermore, we examined the interaction between glutamate receptor interacting protein (GRIP) and GluR2 in the cerebellum because the phosphorylation of GluR2 by PKC $\alpha$ induces the dissociation of GluR2 from GRIP, which is required for LTD induction [18]. The co-immunoprecipitates with the anti-GRIP antibody from cerebellar slices showed the dissociation of GluR2 from GRIP in $\mathrm{tm} 1 \mathrm{c}$ mice during LTD but not in tm1d mice (Figure 3c: tm1c con, 1.00; tm1c K-glu, $0.72 \pm 0.041$; tm1d con, $0.90 \pm 0.039$; tm1d K-glu, $0.90 \pm 0.039$ ). These results indicated that PKC $\alpha$ in tm1d mice was not activated during LTD. Then, to investigate the involvement of abnormal basal PKC $\gamma$ activation in the impaired PKC $\alpha$ phosphorylation during LTD in tm1d mice, we examined the effect of a PKC $\gamma$ inhibitor, scutellarin. Scutellarin normalized the upregulation of basal $\mathrm{PKC} \gamma$ activity in tm1d mice to control ( $\mathrm{tm} 1 \mathrm{c}$ ) level and did not affect the autophosphorylation level of PKC $\gamma$ in $\mathrm{tm} 1 \mathrm{c}$ mice (Figure 3b: tm1c con, 1.00; tm1c K-glu+Scu, $0.98 \pm 0.11$; tm1d con, $1.72 \pm 0.11$; tm1d K-glu+Scu, $1.09 \pm 0.079$ ). Furthermore, the scutellarin treatment normalized the K-glu-induced PKC $\alpha$ phosphorylation and the dissociation of GluR2 from GRIP during LTD in tm1d mice (Figure 3b: tm1d K-glu, $1.10 \pm 0.068$; tm1d K-glu+Scu, $1.36 \pm 0.089$, c: tm1d K-glu, $0.90 \pm 0.039$; tm1d K-glu+Scu, $0.71 \pm 0.058$ ). These results indicated that the upregulated PKC $\gamma$ activity in the basal state inhibits PKC $\alpha$ activation during LTD in tm1d mice.

Next, we focused on a calcium channel, TRPC3, based on the following reports. PKC $\alpha$ activation during LTD requires intracellular $\mathrm{Ca}^{2+}$ increase [19], and TRPC3, which is abundantly expressed in Purkinje cells, is important for motor coordination and LTD [20,21]. Furthermore, PKC $\gamma$ negatively regulates TRPC3 activity and the extracellular $\mathrm{Ca}^{2+}$ influx by the phosphorylation in Ser712 [22,23]. Therefore, we compared the phosphorylation level of TRPC 3 in the cerebellum of tm1d and tm1c mice. The immunoprecipitates with the anti-TRPC 3 antibody from cerebellar slices revealed that the phosphorylation level of TRPC 3 increased in $\mathrm{tm} 1 \mathrm{~d}$ mice compared to in $\mathrm{tm} 1 \mathrm{c}$ mice, although there was no differences in the expression levels of TRPC 3 in the cerebellum of tm1c and tm1d mice (Figure $4 \mathrm{a}, \mathrm{b}$ : tm1c $-\mathrm{Scu}, 1.00 ; \mathrm{tm} 1 \mathrm{~d}-\mathrm{Scu}, 1.50 \pm 0.17)$. Importantly, scutellarin normalized the phosphorylation level of TRPC 3 in tm1d mice to the level in tm1c mice (Figure 4b: tm1d -Scu, $1.50 \pm 0.17$; tm1d $+\mathrm{Scu}$, $0.93 \pm 0.11$ ). This result indicated that the inactivation of TRPC3 by the upregulated PKC $\gamma$ activity inhibited PKC $\alpha$ activation during LTD, leading to cerebellar motor dysfunction in tm1d mice. 


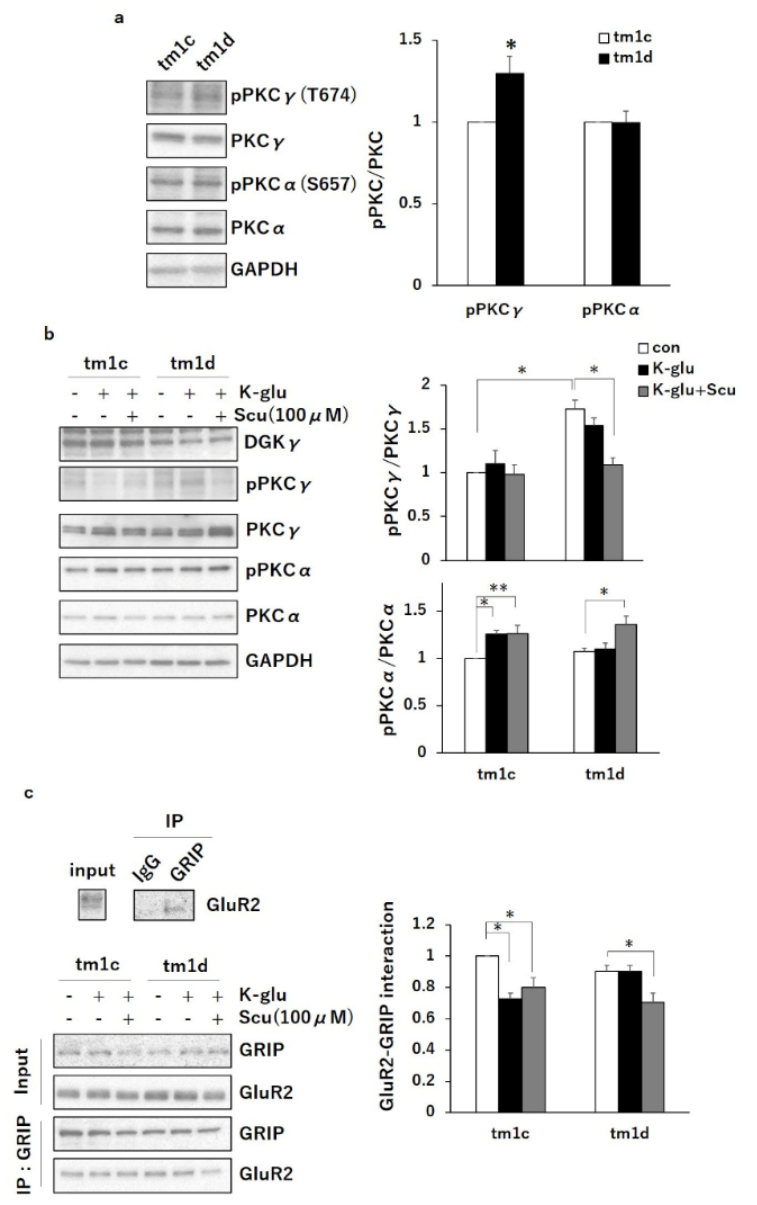

Figure 3. Protein kinase $\mathrm{C} \alpha(\mathrm{PKC} \alpha)$ inactivation during long-term depression (LTD)-induced stimulation by K-glu in tm1d mice: (a) cerebellar lysates from tm1c and tm1d mice were subjected to Western blotting and probed with anti-PKC $\gamma$, anti-PKC $\alpha$, anti-phospho-PKC $\gamma$, anti-phospho-PKC $\alpha$, and anti-GAPDH antibodies. Quantification of the autophosphorylation of PKC $\gamma$ and PKC $\alpha$ was performed by ImageJ. The phosphorylation levels of PKC $\gamma$ and PKC $\alpha$ were normalized to the PKC $\gamma$ and PKC $\alpha$ expression levels. The ratio of phosphorylation of PKC $\gamma$ and PKC $\alpha$ to the expression levels of PKC $\gamma$ and PKC $\alpha$ to tm1c was plotted (PKC $\gamma: \mathrm{n}=3$; PKC $\alpha: \mathrm{n}=3$ ); ${ }^{*} p<0.05$, followed by Student's t-test. (b) Acute cerebellar slices from tm1c and tm1d mice were incubated with or without Scu $(100 \mu \mathrm{m})$ for $1 \mathrm{~h}$ and subsequently were treated with $\mathrm{K}$-glu $(50 \mathrm{mM} \mathrm{KCl}+100 \mu \mathrm{M}$ L-glutamate) for $5 \mathrm{~min}$. Lysates from the slices were subjected to Western blotting and probed with anti-DGK $\gamma$, anti-phospho-PKC $\gamma$, anti-PKC $\gamma$, anti-phospho-PKC $\alpha$, anti-PKC $\alpha$, and anti-GAPDH antibodies. Quantification of the autophosphorylation of PKC $\gamma$ and PKC $\alpha$ was performed by ImageJ. The phosphorylation levels of PKC $\gamma$ and PKC $\alpha$ were normalized to the PKC $\gamma$ and PKC $\alpha$ expression levels. The ratio of phosphorylation of PKC $\gamma$ and PKC $\alpha$ to the control (con) in tm1c was plotted ( $\mathrm{n}=6){ }^{*} p<0.05,{ }^{* *} p<0.01$, followed by Tukey's multiple comparisons test. (c) The lysates after K-glu treatment were immunoprecipitated using anti-glutamate receptor interacting protein (GRIP) antibody. The immunoprecipitates were subjected to western blotting and probed with anti-GRIP and anti-GluR2 antibodies. IgG (anti-transient receptor potential cation channel type 3 (TRPC3) antibody) was used as a control. Quantification of co-immunoprecipitated GluR2 was performed by ImageJ and was normalized to the input level of GluR2. The ratio of the co-immunoprecipitated GluR2 to the control (con) in tm1c was plotted $(\mathrm{n}=6){ }^{*} p<0.05$, followed by Tukey's multiple comparisons test. Data are expressed as mean \pm SEM. Con means control. 


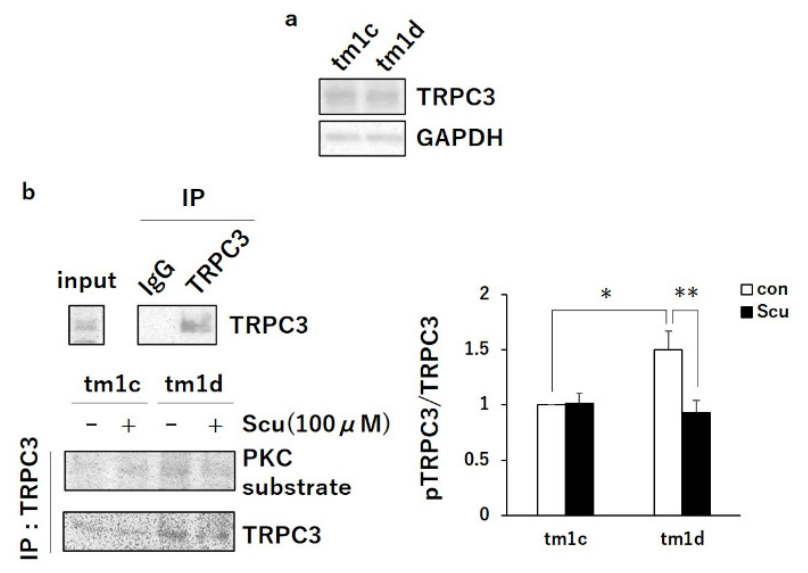

Figure 4. TRPC3 upregulation in tm1d mice: (a) cerebellar lysates from tm1c and tm1d mice were subjected to Western blotting and probed with anti-TRPC3 and anti-GAPDH antibodies. (b) Acute cerebellar slices from tm1c and tm1d mice were incubated with or without Scu $(100 \mu \mathrm{M})$ for $1 \mathrm{~h}$ and subsequently were homogenized. Then, the lysates were immunoprecipitated using anti-TRPC3 antibody. The immunoprecipitates were subjected to western blotting and probed with anti-PKC substrate and anti-TRPC3 antibodies. IgG (anti-GRIP antibody) was used as a control. Quantification of the phosphorylation level of TRPC3 was performed by ImageJ and was normalized to the total level of TRPC3. The ratio of the phosphorylation level of TRPC3 to the control (con) in tm1c was plotted ( $\mathrm{n}=7) ;{ }^{*} p<0.05,{ }^{* *} p<0.01$, followed by Tukey's multiple comparisons test. Data are expressed as mean \pm SEM. Con means control.

\section{Discussion}

In this study, we confirmed the importance of DGK $\gamma$ in motor coordination and the abnormal PKC $\gamma$ upregulation at the basal state using Purkinje cell-specific DGK $\gamma$ KO (tm1d) mice. In addition, we found that the impaired PKC $\alpha$ activation during K-glu impaired LTD in the cerebellar slices from tm1d mice. Similar impairment of PKC $\alpha$ activation during LTD was also detected in the cerebellar slices from the conventional DGK $\gamma$ KO mice, which showed impaired LTD and motor dyscoordination (data not shown). Previously, we showed that LTD in the conventional DGK $\gamma$ KO mice was rescued by a PKC $\gamma$ inhibitor. These results strongly suggested that the upregulated PKC $\gamma$ in both the conventional and Purkinje cell-specific DGK $\gamma$ KO mice somehow inhibited PKC $\gamma$ during LTD, resulting in motor dyscoordination.

PKC $\alpha$ activation to induce cerebellar LTD requires the transient increase in the internal $\mathrm{Ca}^{2+}$ level by coactivation of mGluR1 signaling through PFs and the depolarization through $\mathrm{CF}$, which induce $\mathrm{Ca}^{2+}$ release from the intracellular stores in endoplasmic reticulum (ER) and $\mathrm{Ca}^{2+}$ influx via voltage-dependent calcium channels (VDCCs), respectively [19,24]. TRPC3 also is activated by mGluR1 signaling, inducing a slow excitatory postsynaptic current (EPSC) and a local dendritic $\mathrm{Ca}^{2+}$ signal $[25,26]$, and we found that TRPC 3 is negatively regulated by upregulated $\mathrm{PKC} \gamma$ in tm1d mice in this study, indicating the importance of TRPC3-mediated $\mathrm{Ca}^{2+}$ signaling in Purkinje cells as well as other reports $[20,21,25,27]$. In addition, the disorder of TRPC 3 causes cerebellar motor dyscoordination and impaired LTD, although $\mathrm{Ca}^{2+}$ influx through TRPC3 is 2 to 4 less than the $\mathrm{Ca}^{2+}$ release form ER [28], and recent study reported that TRPC3 activity affected vascular endothelial growth factor (VEGF)-induced PKC $\alpha$ activation in human primary endothelial cells [29]. These results supported our conclusion that the negative regulation of TRPC 3 by upregulated PKC $\gamma$ in the basal state inhibits PKC $\alpha$ activation during LTD, resulting in motor dyscoordination (Figure 5). In other words, DGK $\gamma$ was responsible for cerebellar LTD by the regulation of the basal PKC $\gamma$ activity. On the other hand, $\mathrm{PKC} \gamma$ also regulates DGK $\gamma$ activity. PKC $\gamma$ directly interacts with DGK $\gamma$ and phosphorylates DGK $\gamma$, leading to DGK $\gamma$ activation. Activated DGK $\gamma$ metabolizes DG and subsequently inactivates $\mathrm{PKC} \gamma$ [16]. These results suggested that DGK $\gamma$ and $\mathrm{PKC} \gamma$ mutually regulate each other's activity and that such functional correlation is important for cerebellar coordination. 


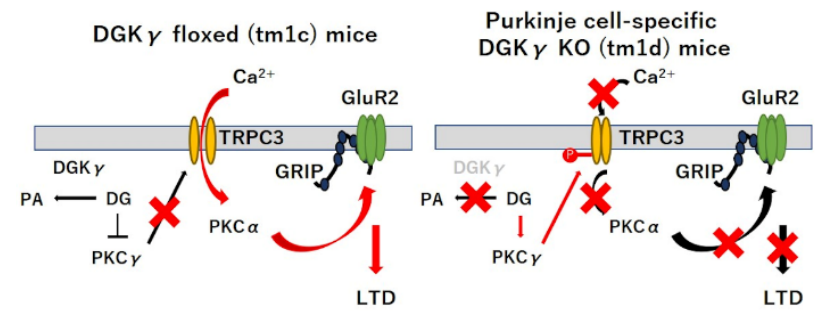

Figure 5. The proposed model of the function of DGK $\gamma$ in the regulation of PKC $\gamma$.

In addition to Purkinje cells, DGK $\gamma$ also is expressed in hippocampal pyramidal cells [14,15], suggesting that DGK $\gamma$ is important for synaptic plasticity in hippocampal neuron. Many research reported DGK subtypes are involved in several forms of hippocampal synaptic plasticity [30]. In addition, $\mathrm{PKC} \gamma$ was also abundantly expressed in hippocampal pyramidal cells and PKC $\gamma$ deficiency causes deficits in LTP and in spatial and contextual learning [31,32]. Therefore, DGK $\gamma$ may also be involved in hippocampal synaptic plasticity by regulation PKC $\gamma$ activity.

Not only DGK $\gamma$ and PKC $\gamma$ but also other DGKs and PKCs are involved in synaptic plasticity [33]. To date, 10 mammalian subtypes of DGK have been identified [34-36], and at least 8 subtypes are expressed in central nervous system (CNS) [37,38]. For example, DGK $\zeta$ physically interacts with PKC $\alpha$, reducing PKC $\alpha$ activity in the basal state, which is responsible for cerebellar LTD [39]. Additionally, DGKe also regulates cerebellar motor coordination by DG metabolization with DG lipase a (DGL $\alpha)[40]$. DGK $\beta$ was characteristically localized at the plasma membrane, which is the hallmark of DGK activation [41]. DGK $\beta$ KO mice showed downregulated postsynaptic long-term potentiation (LTP) at Schaffer-collateral (SC)-CA1 synapses, resulting in impaired cognitive function and hyperactivity [42,43]. DGKı regulates mGluR-dependent LTD at SC-CA1 synapses [44], and DGK乙 and DGKK are responsible for both LTP and LTD at these synapses $[45,46]$. These results suggest that DGKs function as modulators in synaptic plasticity through regulating PKC activity.

In summary, we demonstrated that the precise regulation of the basal PKC $\gamma$ activity by DGK $\gamma$ is crucial for cerebellar LTD. In the basal state, DGK $\gamma$ downregulated PKC $\gamma$ activity by yielding PA from DG, which is the activator of PKC $\gamma$. LTD stimulation can induce PKC $\alpha$ activation by the extracellular $\mathrm{Ca}^{2+}$ influx through TRPC3, leading to internalization of GluR2 and cerebellar LTD. However, in the Purkinje cell-specific DGK $\gamma$ KO (tm1d) mice, upregulated PKC $\gamma$ by DGK $\gamma$ deficiency inactivates TRPC3, leading to PKC $\alpha$ inactivation by the inhibition of $\mathrm{Ca}^{2+}$ influx during LTD stimulation. Our results provide a new understanding into the mechanism underlying cerebellar LTD.

\section{Materials and Methods}

\subsection{Materials}

Primers were purchased from Thermo Fisher scientific (Waltham, MA, USA). We used the following antibodies: rabbit anti-DGK $\gamma$ [14], rabbit anti-PKC substrate (\#2261) (Cell Signaling, Beverly, MA, USA), rabbit anti-phosphor-PKC $\gamma$ T674 (bs-3730R) (Bioss, Woburn, MA, USA), rabbit anti-phosphor-PKC $\alpha$ S657 (ab180848) (Abcam, Cambridge, UK), rabbit anti-PKC $\gamma$ (sc-211), mouse anti-PKC $\alpha$ (sc-8393), mouse anti-TRPC3 (sc-514670), mouse anti-GRIP antibody (sc-365937), mouse anti-GluR2 antibody (sc-517265), mouse anti-GAPDH (sc-47724) (Santa Cruz, Dallas, TX, USA), and peroxidase-conjugated AffiniPure goat anti-rabbit and mouse IgG. Scutellarin was purchased from Namiki Shoji (Tokyo, Japan).

\subsection{Mice}

DGK $\gamma$ floxed (tm1c) mice were used as previously reported [15]. L7/Pcp2-specific Cre recombinase transgenic mice were kindly provided by Dr. Suzuki [47]. Purkinje cell-specific DGK $\gamma(\mathrm{tm} 1 \mathrm{~d})$ mice were generated by mating tm1c mice with $L 7 / P c p 2$-specific Cre recombinase transgenic mice using the Cre-loxP recombination system. These mice were housed under a 12-h light, 12-h dark cycle with ad 
libitum food and water. All procedures using mice were performed according to the guidelines of the Institute Animal Care and Use Committee of Kobe University.

\subsection{Genotyping}

We used the tail-derived genome for PCR genotyping. Genotyping of DGK $\gamma$ gene was determined by PCR using the following primers: 5'-CAGGTGTCTCTTGTCTGGGCT-3' and 5'-TGGGTATAGGGT AGGAACTTGC- $3^{\prime}$. Bands at $975 \mathrm{bp}$ are expected from the DGK $\gamma$ gene. Genotyping of the Cre recombinase gene was conducted by PCR using the following primers: $5^{\prime}$-ATATCCATGAGATTGTCCAT- ${ }^{\prime}$, $5^{\prime}$-GAAGG CTTCTTCAACCTGCT-3' and 5'-GACGTGCTACTTCCATTTGT-3' . Bands at 292-bp and 482-bp are expected from the L7 gene and Cre gene, respectively. PCR conditions were as follows: $25 \mu \mathrm{L}$ volume, 1 cycle at $94{ }^{\circ} \mathrm{C}$ for $2 \mathrm{~min} ; 40$ cycles at $94{ }^{\circ} \mathrm{C}$ for $1 \mathrm{~min}, 62^{\circ} \mathrm{C}(\mathrm{DGK} \gamma)$ or $57^{\circ} \mathrm{C}(\mathrm{Cre})$ for $30 \mathrm{~s}$, and $72{ }^{\circ} \mathrm{C}$ for $1 \mathrm{~min}$; and 1 cycle at $72{ }^{\circ} \mathrm{C}$ for $10 \mathrm{~min}$.

\subsection{Western Blotting}

The cerebellum and cerebrum were homogenized in $500 \mu \mathrm{L}$ ice-cold homogenate buffer (in mM: 20 Tris- $\mathrm{HCl}, 1$ ethylene glycol tetraacetic acid (EGTA), 1 ethylenediaminetetraacetic acid (EDTA), $1 \mathrm{MgCl}_{2}$, and 1 phenylmethylsulfonyl fluoride (PMSF), $20 \mathrm{ng} / \mathrm{mL}$ leupeptin, $1 \times$ phosphatase inhibitor cocktail solution II (Wako, Osaka, Japan), and 1\% Triton X-100, pH 7.4) using Handy Sonic Sonicator (UR-20, Tomy Seiko Co., Ltd., Tokyo, Japan.). After centrifugation at $10,000 \mathrm{rpm}$ for $10 \mathrm{~min}$ at $4{ }^{\circ} \mathrm{C}$, the lysates were obtained.

Western blotting was performed as described previously [41]. Briefly, the samples (10 $\mu$ g protein) were subjected to $10 \%$ SDS-PAGE, followed by blotting onto a poly-vinylidene difluoride membrane (Millipore, Darmstadt, Germany). Nonspecific binding sites were blocked by incubation with 5\% skim milk in $0.01 \mathrm{M}$ phosphate buffered saline (PBS) containing $0.03 \%$ TritonX-100 (PBS-T) for $1 \mathrm{~h}$. The membrane was incubated with the appropriate antibody for $1 \mathrm{~h}$ at room temperature. After washing with PBS-T, the membrane was incubated with peroxidase-labeled anti-rabbit or mouse IgG for $30 \mathrm{~min}$. After three rinses with PBS-T, the immunoreactivity bands were visualized using ImmunoStar (Wako, Osaka, Japan). The densities of the bands were analyzed by ImageJ. To detect phosphorylated protein, we used $2 \%$ bovine serum albumin (BSA) instead of skim milk for blocking and $0.01 \mathrm{M}$ tris buffered saline (TBS) containing $0.03 \%$ Tween 20 (TBS-T) instead of PBS-T.

\subsection{Rotarod Test}

The rotarod apparatus (MK-630B single lane rotarod, Muromachi Kikai Co., LTD., Tokyo, Japan) consisted of a rod ( $30 \mathrm{~mm}$ in diameter, $90 \mathrm{~mm}$ wide) flanked by two large round plates $(40 \mathrm{~cm}$ in diameter). The speed of rotation was increased from 4 to 40 rotation per minute (rpm) over $5 \mathrm{~min}$ and then remained at $40 \mathrm{rpm}$ for an additional $300 \mathrm{~s}$ was maintained for $300 \mathrm{~s}$. We recorded latency for the mice to fall from the rod. The test was performed 3 times daily for 2 days

\subsection{Beam Test}

Mice were trained to traverse elevated metallic beam ( $70 \mathrm{~cm}$ long, $10 \mathrm{~mm}$ in diameter, $60 \mathrm{~cm}$ high). They were placed at one end of the beam, and an enclosed escape box was placed at the other end. Each hind paw slip was recorded and counted. The test was performed 5 times daily for 2 days.

\subsection{Acute Cerebellar Slice}

Acute parasagittal cerebellar slices ( $300 \mu \mathrm{m}$ thick) were prepared from the vermis [48-50]. The slices were incubated in artificial cerebrospinal fluid (ACSF) for $30 \mathrm{~min}$ at $37^{\circ} \mathrm{C}$ and then incubated $1 \mathrm{~h}$ at room temperature in standard ACSF containing picrotoxin $(100 \mu \mathrm{M})$. Scutellarin $(100 \mu \mathrm{M})$ was added into the extracellular solution for $1 \mathrm{~h}$. After that, to chemically induce LTD, the slices were treated with $\mathrm{K}$-glu ( $50 \mathrm{mM} \mathrm{KCl}+100 \mu \mathrm{M}$ glutamate) for $5 \mathrm{~min}$. Then, the slices were subsequently homogenized in 
$100 \mu \mathrm{L}$ lysis buffer (50 mM Tris-HCl, $150 \mathrm{mM} \mathrm{NaCl}, 1 \mathrm{mM}$ EDTA, $1 \mathrm{mM}$ PMSF, $20 \mathrm{ng} / \mathrm{mL}$ leupeptin, $100 \mathrm{mM} \mathrm{NaF}, 2 \mathrm{mM} \mathrm{Na}_{3} \mathrm{VO}_{4}, 20 \mathrm{mM} \mathrm{Na}_{4} \mathrm{P}_{2} \mathrm{O}_{7}, 1 \%$ Triton X-100, and $10 \%$ glycerol, pH 7.5) using Handy Sonic Sonicator. After centrifugation at $10,000 \mathrm{rpm}$ for $10 \mathrm{~min}$ at $4{ }^{\circ} \mathrm{C}$, the lysates $(10 \mu \mathrm{g}$ protein) were subjected to western blotting.

For GRIP-GluR2 interaction, after the slices ( $300 \mu \mathrm{m}$ thick) were homogenized with $100 \mu \mathrm{L}$ lysis buffer and centrifugated, the lysates (500 $\mu$ g protein) were diluted to $1 \mathrm{~mL}$ with homogenate buffer and $0.4 \mu \mathrm{g}$ anti-GRIP antibody was added to the lysates. IgG (anti-TRPC 3 antibody) was used as a control. Then, the lysates were rotated overnight at $4{ }^{\circ} \mathrm{C}$ followed by the addition of $10 \mu \mathrm{L}$ Protein $\mathrm{G}$ sepharose and rotated for $2 \mathrm{~h}$ at $4{ }^{\circ} \mathrm{C}$. After centrifugation at 10,000 rpm for $1 \mathrm{~min}$ at $4{ }^{\circ} \mathrm{C}$ for wash out with homogenate buffer, the immunoprecipitates were subjected to western blotting.

For TRPC3 phosphorylation, freshly prepared cerebellar slices (300 $\mu \mathrm{m}$ thick) were incubated in ACSF for $30 \mathrm{~min}$ at $37^{\circ} \mathrm{C}$ and then incubated $1 \mathrm{~h}$ at room temperature in standard ACSF containing picrotoxin $(100 \mu \mathrm{M})$ and scutellarin $(100 \mu \mathrm{M})$. After the slices were then homogenized with $100 \mu \mathrm{L}$ lysis buffer and centrifugated, the lysates (500 $\mu$ g protein) were diluted to $1 \mathrm{~mL}$ with PBS-T and $0.4 \mu \mathrm{g}$ anti-TRPC3 antibody was added to the lysates. IgG (anti-GRIP antibody) was used as a control.

Then, the lysates were rotated for $2 \mathrm{~h}$ at $4{ }^{\circ} \mathrm{C}$ followed by the addition of $10 \mu \mathrm{L}$ Protein $\mathrm{G}$ sepharose and rotated for $1 \mathrm{~h}$ at $4{ }^{\circ} \mathrm{C}$. After centrifugation at $10,000 \mathrm{rpm}$ for $1 \mathrm{~min}$ at $4{ }^{\circ} \mathrm{C}$ for wash out with PBS-T, the immunoprecipitates were subjected to western blotting.

\subsection{Experimental Design and Statistical Analysis}

All animal data were analyzed for male mice. All data are shown as the means \pm SEM, and Student's $\mathrm{t}$-tests and Tukey's multiple comparison test were used as appropriate to test statistical significance. Data were analyzed using Excel (Microsoft, Seattle, WA, USA) and R version 3.5.1 (The R Foundation for Statistical Computing, Vienna, Austria). Differences were considered significant when $p<0.05$.

Author Contributions: Conceptualization, Y.S.; methodology, R.T., S.K. and Y.S.; validation, R.T.; formal analysis, R.T.; investigation, R.T. and K.M.; resources, H.S. and N.S.; data curation, R.T.; writing-original draft preparation, R.T.; writing-review and editing, Y.S.; visualization, R.T.; supervision, S.K., S.U., M.Y. and Y.S.; project administration, Y.S. All authors have read and agreed to the published version of the manuscript.

Funding: This research received no external funding.

Acknowledgments: We thank Saito and Suzuki for supplying L7/Pcp2-specific Cre recombinase transgenic mice.

Conflicts of Interest: The authors declare no conflict of interest. The funders had no role in the design of the study; in the collection, analyses, or interpretation of data; in the writing of the manuscript; or in the decision to publish the results.

\section{Abbreviations}

$\begin{array}{ll}\text { AMPA } & \alpha \text {-amino-3-hydroxy-5-methylisoxazole-4-propionic acid } \\ \text { CF } & \text { Climbing fiber } \\ \text { CNS } & \text { Central nervous system } \\ \text { DGK } & \text { Diacylglycerol kinase } \\ \text { DGL } & \text { Diacylglycerol lipase } \\ \text { EPSC } & \text { Excitatory postsynaptic current } \\ \text { GRIP } & \text { Glutamate receptor interacting protein } \\ \text { K-glu } & \text { KCl-L-glutamate } \\ \text { LTD } & \text { Long-term depression } \\ \text { LTP } & \text { Long-term potentiation } \\ \text { mGluR1 } & \text { Metabotropic glutamate receptor 1 } \\ \text { mTOR } & \text { Mammalian of target of rapamycin } \\ \text { PA } & \text { Phosphatidic acid } \\ \text { PFs } & \text { Parallel fibers } \\ \text { PKC } & \text { Protein kinase C } \\ \text { SC } & \text { Schaffer-collateral } \\ \text { TRPC3 } & \text { Nonselective transient receptor potential cation channel type 3 } \\ \text { VDCCs } & \text { Voltage dependent calcium channels }\end{array}$




\section{References}

1. Ito, M. The molecular organization of cerebellar long-term depression. Nat. Rev. Neurosci. 2002, 3, 896-902. [CrossRef] [PubMed]

2. Kano, M.; Hashimoto, K.; Tabata, T. Type-1 metabotropic glutamate receptor in cerebellar Purkinje cells: A key molecule responsible for long-term depression, endocannabinoid signalling and synapse elimination. Philos. Trans. R. Soc. Lond. B Biol. Sci. 2008, 363, 2173-2186. [CrossRef] [PubMed]

3. Lüscher, C.; Huber, K.M. Group 1 mGluR-dependent synaptic long-term depression: Mechanisms and implications for circuitry and disease. Neuron 2010, 65, 445-459. [CrossRef] [PubMed]

4. Chung, H.J.; Steinberg, J.P.; Huganir, R.L.; Linden, D.J. Requirement of AMPA receptor GluR2 phosphorylation for cerebellar long-term depression. Science 2003, 300, 1751-1755. [CrossRef] [PubMed]

5. Xia, J.; Chung, H.J.; Wihler, C.; Huganir, R.L.; Linden, D.J. Cerebellar long-term depression requires PKC-regulated interactions between GluR2/3 and PDZ domain-containing proteins. Neuron 2000, 28, 499-510. [CrossRef]

6. Leitges, M.; Kovac, J.; Plomann, M.; Linden, D.J. A unique PDZ ligand in PKC $\alpha$ confers induction of cerebellar long-term synaptic depression. Neuron 2004, 44, 585-594. [CrossRef]

7. Lee, D.; Yamamoto, Y.; Kim, E.; Tanaka-Yamamoto, K. Functional and physical interaction of diacylglycerol kinase zeta with protein kinase Calpha Is required for cerebellar long-term depression. J. Neurosci. 2015, 35, 15453-15465. [CrossRef]

8. Chen, C.; Kano, M.; Abeliovich, A.; Chen, L.; Bao, S.; Kim, J.J.; Hashimoto, K.; Thompson, R.F.; Tonegawa, S. Impaired motor coordination correlates with persistent multiple climbing fiber innervation in PKC $\gamma$ mutant mice. Cell 1995, 83, 1233-1242. [CrossRef]

9. Saito, N.; Shirai, Y. Protein kinase $\mathrm{C} \gamma(\mathrm{PKC} \gamma)$ : Function of neuron specific isotype. J. Biochem. 2002, 132, 683-687. [CrossRef]

10. Shuvaev, A.N.; Horiuchi, H.; Seki, T.; Goenawan, H.; Irie, T.; Iizuka, A.; Sakai, N.; Hirai, H. Mutant PKC $\gamma$ in spinocerebellar ataxia type 14 disrupts synapse elimination and long-term depression in Purkinje cells in vivo. J. Neurosci. 2011, 31, 14324-14334. [CrossRef]

11. Sakane, F.; Imai, S.I.; Kai, M.; Yasuda, S.; Kanoh, H. Diacylglycerol kinases: Why so many of them? Biochim. Biophys. Acta Mol. Cell Biol. Lipids 2007, 1771, 793-806. [CrossRef] [PubMed]

12. Almena, M.; Mérida, I. Shaping up the membrane: Diacylglycerol coordinates spatial orientation of signaling. Trends Biochem. Sci. 2011, 36, 593-603. [CrossRef] [PubMed]

13. Fang, Y.; Vilella-Bach, M.; Bachmann, R.; Flanigan, A.; Chen, J. Phosphatidic acid-mediated mitogenic activation of mTOR signaling. Science 2001, 294, 1942-1945. [CrossRef] [PubMed]

14. Adachi, N.; Oyasu, M.; Taniguchi, T.; Yamaguchi, Y.; Takenaka, R.; Shirai, Y.; Saito, N. Immunocytochemical localization of a neuron-specific diacylglycerol kinase $\beta$ and $\gamma$ in the developing rat brain. Mol. Brain Res. 2005, 139, 288-299. [CrossRef]

15. Tsumagari, R.; Kakizawa, S.; Kikunaga, S.; Fujihara, Y.; Ueda, S.; Yamanoue, M.; Saito, N.; Ikawa, M.; Shirai, Y. DGK $\gamma$ knockout mice show impairments in cerebellar motor coordination, LTD and the dendritic development of Purkinje cells through the activation of PKC $\gamma$. Eneuro 2020, 7. [CrossRef]

16. Yamaguchi, Y.; Shirai, Y.; Matsubara, T.; Sanse, K.; Kuriyama, M.; Oshiro, N.; Yoshino, K.; Yonezawa, K.; Ono, Y.; Saito, N. Phosphorylation and up-regulation of diacylglycerol kinase $\gamma$ via its interaction with protein kinase C $\gamma$. J. Biol. Chem. 2006, 281, 31627-31637. [CrossRef]

17. Hirai, H. Protein kinase $C$ in the cerebellum: Its significance and remaining conundrums. Cerebellum 2018, 17, 23-27. [CrossRef]

18. Matsuda, S.; Mikawa, S.; Hirai, H. Phosphorylation of serine-880 in GluR2 by protein kinase C prevents its $\mathrm{C}$ terminus from binding with glutamate receptor-interacting protein. J. Neurochem. 1999, 73, 1765-1768. [CrossRef] [PubMed]

19. Gallimore, A.R.; Kim, T.; Tanaka-Yamamoto, K.; De Schutter, E. Switching on depression and potentiation in the cerebellum. Cell Rep. 2018, 22, 722-733. [CrossRef]

20. Hartmann, J.; Dragicevic, E.; Adelsberger, H.; Henning, H.A.; Sumser, M.; Abramowitz, J.; Blum, R.; Dietrich, A.; Freichel, M.; Flockerzi, V.; et al. TRPC3 channels are required for synaptic transmission and motor coordination. Neuron 2008, 59, 392-398. [CrossRef]

21. Kim, S.J. TRPC3 channel underlies cerebellar long-term depression. Cerebellum 2013, 12, $334-337$. [CrossRef] [PubMed] 
22. Adachi, N.; Kobayashi, T.; Takahashi, H.; Kawasaki, T.; Shirai, Y.; Ueyama, T.; Matsuda, T.; Seki, T.; Sakai, N.; Saito, N. Enzymological analysis of mutant protein kinase Cgamma causing spinocerebellar ataxia type 14 and dysfunction in Ca2+ homeostasis. J. Biol. Chem. 2008, 283, 19854-19863. [CrossRef] [PubMed]

23. Trebak, M.; Hempel, N.; Wedel, B.J.; Smyth, J.T.; Bird, G.S.J.; Putney, J.W. Negative regulation of TRPC3 channels by protein kinase C-mediated phosphorylation of serine 712. Mol. Pharmacol. 2005, 67, 558-563. [CrossRef]

24. Daniel, H.; Hemart, N.; Jaillard, D.; Crepel, F. Coactivation of metabotropic glutamate receptors and of voltage-gated calcium channels induces long-term depression in cerebellar Purkinje cells in vitro. Exp. Brain Res. 1992, 90, 327-331. [CrossRef] [PubMed]

25. Hartmann, J.; Henning, H.A.; Konnerth, A. mGluR1/TRPC3-mediated synaptic transmission and calcium signaling in mammalian central neurons. Cold Spring Harb. Perspect. Biol. 2011, 3, 1-16. [CrossRef] [PubMed]

26. Lemonnier, L.; Trebak, M.; Putney, J.W. Complex regulation of the TRPC3, 6 and 7 channel subfamily by diacylglycerol and phosphatidylinositol-4,5-bisphosphate. Cell Calcium 2008, 43, 506-514. [CrossRef] [PubMed]

27. Becker, E.B.E.; Oliver, P.L.; Glitsch, M.D.; Banks, G.T.; Achillic, F.; Hardy, A.; Nolan, P.M.; Fisher, E.M.C.; Davies, K.E. A point mutation in TRPC 3 causes abnormal Purkinje cell development and cerebellar ataxia in moonwalker mice. Proc. Natl. Acad. Sci. USA 2009, 106, 6706-6711. [CrossRef]

28. Canepari, M.; Papageorgiou, G.; Corrie, J.E.T.; Watkins, C.; Ogden, D. The conductance underlying the parallel fibre slow EPSP in rat cerebellar Purkinje neurones studied with photolytic release of L-glutamate. J. Physiol. 2001, 533, 765-772. [CrossRef]

29. Andrikopoulos, P.; Eccles, S.A.; Yaqoob, M.M. Coupling between the TRPC3 ion channel and the NCX1 transporter contributed to VEGF-induced ERK1/2 activation and angiogenesis in human primary endothelial cells. Cell. Signal. 2017, 37, 12-30. [CrossRef]

30. Lee, D.; Kim, E.; Tanaka-Yamamoto, K. Diacylglycerol kinases in the coordination of synaptic plasticity. Front. Cell Dev. Biol. 2016, 4, 92. [CrossRef] [PubMed]

31. Abeliovich, A.; Chen, C.; Goda, Y.; Silva, A.J.; Stevens, C.F.; Tonegawa, S. Modified hippocampal long-term potentiation in PKC $\gamma$-mutant mice. Cell 1993, 75, 1253-1262. [CrossRef]

32. Abeliovich, A.; Paylor, R.; Chen, C.; Kim, J.J.; Wehner, J.M.; Tonegawa, S. PKC $\gamma$ mutant mice exhibit mild deficits in spatial and contextual learning. Cell 1993, 75, 1263-1271. [CrossRef]

33. Barber, C.N.; Raben, D.M. Roles of DGKs in neurons: Postsynaptic functions? Adv. Biol. Regul. 2020, 75, 100688. [CrossRef] [PubMed]

34. Topham, M.K.; Prescott, S.M. Mammalian diacylglycerol kinases, a family of lipid kinases with signaling functions. J. Biol. Chem. 1999, 274, 11447-11450. [CrossRef] [PubMed]

35. Kanoh, H.; Yamada, K.; Sakane, F. Diacylglycerol kinases: Emerging downstream regulators in cell signaling systems. J. Biochem. 2002, 131, 629-633. [CrossRef]

36. Van Blitterswijk, W.J.; Houssa, B. Properties and functions of diacylglycerol kinases. Cell. Signal. 2000, 12, 595-605. [CrossRef]

37. Raben, D.M.; Tu-Sekine, B. Regulation and roles of neuronal diacylglycerol kinases: A lipid perspective. Crit. Rev. Biochem. Mol. Biol. 2011, 46, 353-364. [CrossRef]

38. Shirai, Y.; Saito, N. Diacylglycerol kinase as a possible therapeutic target for neuronal diseases. J. Biomed. Sci. 2014, 21, 28. [CrossRef]

39. Luo, B.; Prescott, S.M.; Topham, M.K. Association of diacylglycerol kinase zeta with protein kinase C alpha: Spatial regulation of diacylglycerol signaling. J. Cell Biol. 2003, 160, 929-937. [CrossRef]

40. Hozumi, Y.; Fujiwara, H.; Kaneko, K.; Fujii, S.; Topham, M.K.; Watanabe, M.; Goto, K. Diacylglycerol kinase $\varepsilon$ localizes to subsurface cisterns of cerebellar Purkinje cells. Cell Tissue Res. 2017, 1-18. [CrossRef]

41. Kano, T.; Kouzuki, T.; Mizuno, S.; Ueda, S.; Yamanoue, M.; Sakane, F.; Saito, N.; Shirai, Y. Both the C1 domain and a basic amino acid cluster at the C-terminus are important for the neurite and branch induction ability of DGK $\beta$. Biochem. Biophys. Res. Commun. 2014, 447, 89-94. [CrossRef] [PubMed]

42. Shirai, Y.; Kouzuki, T.; Kakefuda, K.; Moriguchi, S.; Oyagi, A.; Horie, K.; Morita, S.; Shimazawa, M.; Fukunaga, K.; Takeda, J.; et al. Essential role of neuron-enriched diacylglycerol kinase (DGK), DGK $\beta$ in neurite spine formation, contributing to cognitive function. PLoS ONE 2010, 5, e11602. [CrossRef] [PubMed]

43. Ishisaka, M.; Kakefuda, K.; Oyagi, A.; Ono, Y.; Tsuruma, K.; Shimazawa, M.; Kitaichi, K.; Hara, H. Diacylglycerol kinase $\beta$ knockout mice exhibit attention-deficit behavior and an abnormal response on methylphenidate-induced hyperactivity. PLOS ONE 2012, 7, e37058. [CrossRef] [PubMed] 
44. Yang, J.; Seo, J.; Nair, R.; Han, S.; Jang, S.; Kim, K.; Han, K.; Paik, S.K.; Choi, J.; Lee, S.; et al. DGKı regulates presynaptic release during mGluR-dependent LTD. EMBO J. 2011, 30, 165-180. [CrossRef] [PubMed]

45. Seo, J.; Kim, K.; Jang, S.; Han, S.; Choi, S.Y.; Kim, E. Regulation of hippocampal long-term potentiation and long-term depression by diacylglycerol kinase $\zeta$. Hippocampus 2012, 22, 1018-1026. [CrossRef]

46. Tabet, R.; Moutin, E.; Becker, J.A.J.; Heintz, D.; Fouillen, L.; Flatter, E.; Krȩzel, W.; Alunni, V.; Koebel, P.; Dembélé, D.; et al. Fragile X mental retardation protein (FMRP) controls diacylglycerol kinase activity in neurons. Proc. Natl. Acad. Sci. USA 2016, 113, E3619-E3628. [CrossRef]

47. Saito, H.; Tsumura, H.; Otake, S.; Nishida, A.; Furukawa, T.; Suzuki, N. L7/Pcp-2-specific expression of Cre recombinase using knock-in approach. Biochem. Biophys. Res. Commun. 2005, 331, 1216-1221. [CrossRef]

48. Edwards, F.A.; Konnerth, A.; Sakmann, B.; Takahashi, T. A thin slice preparation for patch clamp recordings from neurones of the mammalian central nervous system. Pflügers Arch. Eur. J. Physiol. 1989, 414, 600-612. [CrossRef]

49. Kakizawa, S.; Yamasaki, M.; Watanabe, M.; Kano, M. Critical period for activity-dependent synapse elimination in developing cerebellum. J. Neurosci. 2000, 20, 4954-4961. [CrossRef]

50. Kakizawa, S.; Yamazawa, T.; Chen, Y.; Ito, A.; Murayama, T.; Oyamada, H.; Kurebayashi, N.; Sato, O.; Watanabe, M.; Mori, N.; et al. Nitric oxide-induced calcium release via ryanodine receptors regulates neuronal function. EMBO J. 2012, 31, 417-428. [CrossRef]

Publisher's Note: MDPI stays neutral with regard to jurisdictional claims in published maps and institutional affiliations.

(C) 2020 by the authors. Licensee MDPI, Basel, Switzerland. This article is an open access article distributed under the terms and conditions of the Creative Commons Attribution (CC BY) license (http://creativecommons.org/licenses/by/4.0/). 